\title{
Frequency and awareness of caffeine consumption among the medical students.
}

1. MBBS, MPH, MSc, MHPE Professor Community Medicine \& Medical Educationist Rawal Institute of Health Sciences, Islamabad.

Correspondence Address:

Prof. Dr.Uzma Hassan House No-24. Army Officers Housing Colony.

National Park Road. Rawalpindi. Pakistan.

dr.uzma.hassan@gmail.com

Article received on: 09/03/2020

Accepted for publication: $30 / 05 / 2020$

\begin{abstract}
Uzma Hassan ${ }^{1}$
ABSTRACT... Objectives: To evaluate the frequency and awareness of caffeine consumption among medical students. Study Design: Descriptive Cross-sectional study. Setting: Rawal Institute of Health Sciences Islamabad. Period: April 2018- October 2018. Material \& Methods: Study carried out on 220 medical students both male and female of first year to final year class of Rawal Institute of Health Sciences Islamabad, using the non-probability convenience sampling method. The interview method was used by filling the structured close ended questionnaire by the researcher (myself). The questions asked were about different parameters related to frequency of caffeine consumption among students like; gender distribution, preferred choice of caffeine and caffeine awareness among medical students. The responses were noted and the frequencies calculated in percentages. Results: Out of 220 respondents, majority students were females 128 (58.2\%), maximum from third year class 78 (35.5\%). Response to different questions was as follows; Preferred choice of caffeine was tea 92 (42.8\%). Daily intake of caffeine was less than 5 cups 128 (58.2\%), Season of increased consumption was summers 109 (49.6\%), total years of caffeine consumption was 11-16 years $182(82.7 \%)$, feel energetic with caffeine $142(64.5 \%)$, feel agitated without caffeine $105(47.7 \%)$, developed habit from family 122 (55.5\%). Can survive without caffeine 132 $(60 \%)$, caffeine damages the body $136(61.8 \%)$, caffeine benefits the body $122(55.5 \%)$, willing to quit caffeine $154(70 \%)$. Conclusion: The results showed that majority of students were using caffeine without sufficient awareness of its adverse effects, withdrawal symptoms and benefits.
\end{abstract}

Key words: $\quad$ Awareness, Caffeine, Consumption, Frequency.

Article Citation: Hassan U. Frequency and awareness of caffeine consumption among the medical students. Professional Med J 2020; 27(12):2763-2768.

https://doi.org/10.29309/TPMJ/2020.27.12.4631

\section{INTRODUCTION}

Caffeine consumption is increasing steadily among medical students in Pakistan. The highly competitive nature of the medical field and the hard work required has increased the uptake of caffeine by medical students in order to be able to work for more hours with higher level of concentration. This increase in uptake has also increased the monetary demands of the medical students.

For majority of caffeine consumers exposure is often life-long. ${ }^{1}$ If not correctly monitored its continuous use may lead to dependence associated with disadvantages and damaging withdrawal symptoms and side effects. Heavy caffeine consumption has been associated with depression and anxiety disorders. These conditions have been known to cause failure among students from all the fields. ${ }^{2}$

Today energy drinks which are designed to increase mental alertness and physical performance of consumers contain large amount of caffeine. They have become a modern form of caffeine intake even among medical students. These drinks along with their desired effects also effect the body adversely. ${ }^{3}$

Caffeine is a naturally occurring stimulant that can be isolated from more than sixty plants and can also be made synthetically. It is a central nervous system stimulant belongs to the group of xanthine and is a central nervous stimulant. ${ }^{4}$ 
It is estimated that caffeine is used by more than $80 \%$ population of the world. Being world's most popular psychoactive substance, it is estimated that annual global consumption of caffeine is around 120,000 tons which makes $70 \mathrm{mg}$ per inhabitant per day. In last 30 years, 19,000 studies on caffeine and coffee have been carried out with an aim to uncover the effects caffeine on the human body. ${ }^{4}$

After 20 minutes, $90 \%$ of caffeine consumed through a coffee cup is cleared from stomach. This orally consumed caffeine takes its effects within an hour and last for 3-4 hours. ${ }^{4}$ The peak plasma concentration is reached in about 4060 minutes with a half-life of about six hours in heathy adults. The half-life is lesser in smokers and greater in pregnant ladies and women using oral contraceptive medications. ${ }^{5}$

Its effects include excessive changes in the body such as increased blood pressure, anxiety disorders, glaucoma, irritable bowel, nausea, tremors, difficulty in sleeping, hyperglycemia..$^{5-7}$ Caffeine withdrawal symptoms include headaches, fatigue, physical activity decreased energy and alertness, drowsiness, depressed mood, difficulty in concentrating, and irritability. The intake of caffeine has an effect on the circulatory system of the body through direct myocardial stimulation thus increasing the respiratory rate along with the gastric secretion. Such effects are taken as adverse effects of the caffeine. Moreover, daily consumption of caffeine in excess of 500-600 milligrams may cause insomnia, nervousness, restlessness and muscle tremors. ${ }^{4}$ The withdrawal symptoms occurs approximately between 12-24 hours after abstinence, and with peak intensity around 20-51 hours and may last for about a week or so. ${ }^{4}$

A psychoactive substance in one which causes increase alertness and deferral of fatigue. ${ }^{8}$ This number was equal to one serving of a caffeinated drink for every individual per day. The percentage In North America is about $90 \%$ of adults consume some amount of caffeine drink on daily basis.

Dependence of caffeine is quite common among the medical students and is increasing at alarming speed. The wide spread use may be because its habitual consumption has been related to enhanced self-reported alertness, superior presentation of vigilant tasks and lesser gaps in attention. ${ }^{3}$

In Pakistan, medical students have a variety of caffeine choices available to decide from, such as tea, coffee, soft drinks, caffeine tablets and patches. Companies market their products to young generation specially students.

The rationale of this research has high significance because the abuse of caffeine among students is of paramount importance due to its serious health implications. By determining the reasons of its high consumption and trends will help in implementation to limit the use among students. ${ }^{4}$

The objective of this study was to evaluate the frequency and awareness of Caffeine consumption among medical students.

\section{MATERIAL \& METHODS}

This descriptive cross-sectional study was carried out on 220 medical students of Rawal Institute of Health Sciences, Islamabad. Data was collected in six months duration from 15 April to 15 October 2018 by the non-probability convenience sampling method. The objective of the study was to evaluate the frequency and awareness of Caffeine consumption among the medical students. The respondents were the medical students both male and female of first year to final year MBBS ( $1^{\text {st }}$ year, $2^{\text {nd }}$ year, $3^{\text {rd }}$ year, $4^{\text {th }}$ year, and final year). The interview method was used by filling the structured close ended questionnaire by the researcher (myself). Prior approval was taken from the ethical review board of the Institute before collecting data. Informed consent was taken from the study subjects and confidentiality of the participants was assured. Pilot study was conducted on 20 respondents and changes were made in the questionnaire accordingly.

The Questionnaire was divided into two parts. First part of the questionnaire (Part A) was the 
profile of the respondents such as class (year) in the medical college, age, gender, educational status of the parents. The second part (Part B) was the questions about different parameters which were related to the frequency and awareness of caffeine consumption among medical students. The questions asked were as follows; Preferred choice of caffeine consumption (coffee, tea, soda, energy drinks). Daily intake of caffeine (less than 5 cups, 5-10 cups, more than 10 cups). Season of increased consumption (winters, summers, no difference). Total years of caffeine consumption (5-10 years, $11-16$ years, more than 17 years). Feel with /after caffeine consumption (same, energetic, euphoric). Feel without caffeine consumption (agitated, exhausted, depressed, no change in mood). Developed the habit of caffeine consumption (from family, from friends, from professional colleagues). Can you survive without caffeine consumption (yes, no, don't know). Caffeine consumption damages the body (yes, no, don't know).Caffeine consumption benefits the body (yes, no, don't know). Willing to quit caffeine consumption (yes, know, don't know). The responses were noted in frequencies and calculated in percentages.

\section{RESULTS}

Out of total respondents $(n=220)$ the number of medical students belonging to different classes were: First Year 28 (12.7\%), Second Year 32 (14.5\%), Third Year 78 (35.5\%), Fourth Year 54 (24.6\%) and Final Year 28 (12.7\%) (Table-I). Frequency of gender distribution was (male $n=92$,
$41.8 \%)$ and females $(n=128,58.2 \%)$ (Table-II).

Preferred choice of Caffeine Consumption among medical Students was in the form of tea $(n=94,42.7 \%)$ (Table-III). The responses to Parameters related to Caffeine Consumption among medical Students was as follows; Majority $(n=128,58.2 \%)$ had less than 5 cups of caffeine per day. Maximum intake was in Summer season $(n=109,49.6 \%)$. Maximum years of Caffeine consumption was noted as $11-16$ years $(n=182,82.7 \%)$. Majority $(n=142$, $64.5 \%)$ felt energetic after caffeine, Majority $(n=105,47.7 \%)$ felt agitated without caffeine consumption. The maximum number of students $(n=122,55.5 \%)$ developed habit from family members. (Table-IV). The responses to awareness regarding Caffeine Consumption among medical Students is shown in (Table-V).

\section{DISCUSSION}

Caffeine is the most widely used substance around the world. This study is conducted on medical students, wherein majority reported the use in the forms, coffee, tea, soda and energy drinks. Caffeine consumption was found popular among students. With students from all academic year group participating in this study with high response rate, it can be stated that the results represent the target population, indicating that $100 \%$ of all participants use caffeine on daily basis in one form or another with maximum consumption through coffee. Female students (58\%) were consuming more caffeine as compared to male students (42\%).

\begin{tabular}{|l|c|c|c|c|c|}
\hline \multirow{2}{*}{ Variable } & \multicolumn{5}{|c|}{ Different Classes of Medical College } \\
\cline { 2 - 5 } & $\mathbf{1}^{\text {st }}$ Year & $2^{\text {nd }}$ year & $3^{\text {rd }}$ year & $4^{\text {th }}$ year & $\mathbf{5}^{\text {th }}$ year \\
\hline Number of students & $28(12.7 \%)$ & $32(14.5 \%)$ & $78(35.5 \%)$ & $54(24.6 \%)$ & $28(12.7 \%)$ \\
\hline
\end{tabular}

Table-I. Frequency of medical students of different classes $(n=220)$

\begin{tabular}{|l|c|c|}
\hline \multicolumn{1}{|c|}{ Variable } & Male & Female \\
\hline Gender Distribution & $92(41.8 \%)$ & $128(58.2 \%)$ \\
\hline
\end{tabular}

Table-II. Frequency of gender distribution among medical students $(n=220)$

\begin{tabular}{|l|c|c|c|c|}
\hline \multicolumn{1}{|c|}{ Variable } & \multicolumn{3}{|c|}{ Options } \\
\cline { 2 - 4 } & Coffee & Tea & Soda & Energy Drinks \\
\hline Preferred choice of Caffeine consumption & $64(29.1 \%)$ & $94(42.7 \%)$ & $48(21.8 \%)$ & $14(6.4 \%)$ \\
\hline
\end{tabular}

Table-III. Frequency of preferred choice of caffeine consumption among medical students $(n=220)$ 


\begin{tabular}{|c|c|c|c|}
\hline $\begin{array}{l}\text { Variables Related to } \\
\text { Caffeine Consumption }\end{array}$ & \multicolumn{3}{|c|}{ Options } \\
\hline $\begin{array}{l}\text { Daily Intake of Caffeine } \\
\text { Consumption. }\end{array}$ & $\begin{array}{l}\text { Less than } 5 \text { Cups } \\
128(58.2 \%)\end{array}$ & $\begin{array}{l}5-10 \text { Cups } \\
74(33.6 \%)\end{array}$ & $\begin{array}{c}\text { More than } 10 \text { Cups } \\
18(8.2 \%)\end{array}$ \\
\hline $\begin{array}{l}\text { Season of increased Caffeine } \\
\text { consumption. }\end{array}$ & $\begin{array}{c}\text { Winters } \\
101(45.9 \%)\end{array}$ & $\begin{array}{l}\text { Summers } \\
109(49.6 \%)\end{array}$ & $\begin{array}{c}\text { No difference } \\
10(4.5 \%)\end{array}$ \\
\hline $\begin{array}{l}\text { Total years of Caffeine } \\
\text { consumption. }\end{array}$ & $\begin{array}{l}5-10 \text { years } \\
22(10 \%)\end{array}$ & $\begin{array}{l}11-16 \text { years } \\
182(82.7 \%)\end{array}$ & $\begin{array}{c}\text { More than } 17 \text { years } \\
16(7.3 \%)\end{array}$ \\
\hline $\begin{array}{l}\text { Feel with /after Caffeine } \\
\text { consumption. }\end{array}$ & $\begin{array}{c}\text { Same } \\
64(29.1 \%)\end{array}$ & $\begin{array}{c}\text { Energetic } \\
142(64.5 \%)\end{array}$ & $\begin{array}{l}\text { Euphoric } \\
14(6.4 \%)\end{array}$ \\
\hline $\begin{array}{l}\text { Feel without Caffeine } \\
\text { consumption. }\end{array}$ & $\begin{array}{c}\text { Agitated } \\
105(47.7 \%)\end{array}$ & $\begin{array}{l}\text { Exhausted } \\
89(40.5 \%)\end{array}$ & $\begin{array}{l}\text { Depressed } \\
26(11.8 \%)\end{array}$ \\
\hline $\begin{array}{l}\text { Developed habit of Caffeine } \\
\text { consumption from. }\end{array}$ & $\begin{array}{c}\text { Family } \\
122(55.5 \%)\end{array}$ & $\begin{array}{c}\text { Friends } \\
70(31.8 \%)\end{array}$ & $\begin{array}{l}\text { Colleagues } \\
28(12.7 \%)\end{array}$ \\
\hline
\end{tabular}

Table-IV. Frequency of parameters related to caffeine consumption among medical students $(n=220)$

\begin{tabular}{|c|c|c|c|}
\hline \multirow{2}{*}{$\begin{array}{l}\text { Variables Related to Awareness of Caffeine } \\
\text { Consumption }\end{array}$} & \multicolumn{3}{|c|}{ Options } \\
\hline & Yes & No & Don’t Know \\
\hline Can you survive without Caffeine consumption & $132(60 \%)$ & $68(30.9 \%)$ & $20(12.7 \%)$ \\
\hline Caffeine consumption benefits the body. & $63(28.6 \%)$ & $122(55.5 \%)$ & $35(15.9 \%)$ \\
\hline Willing to quit Caffeine consumption. & $44(20 \%)$ & $154(70 \%)$ & $22(10 \%)$ \\
\hline
\end{tabular}

Majority of the participants (83\%) are consuming caffeine for last 11 to 16 years and started it through the influence of their family and peers (87\%). A study from Serbia ${ }^{9}$ and Turkey ${ }^{10}$ revealed that the common reasons for caffeine intake among adolescents were leisure, peer influence and habit.

In consistent with other studies ${ }^{3,4,11-15}$, it was also found that students consume a considerable quantity of caffeine on daily basis irrespective of the season (summer or winter). Tea (43\%) is the top of caffeine source followed by coffee (29\%) and cold drinks (22\%). The same result has been found in an study carried out at Dow University of Health Science. ${ }^{14}$ In another study, the major consumption was through coffee and soft drinks. However, the results in this study ${ }^{16}$ showed that about $(52 \%)$ of the consumers drink both coffee followed by tea (34\%).

According to the students, caffeine is consumed mainly to feel energetic (65\%). In other studies ${ }^{12,14}$, it was found that major reason for consumption is to stay alert during overnight studies. These studies reported no significant association of caffeine consumption towards enhancing the academic performance. Majority of respondents perceived that it decreases workload and stress while increasing the academic performance. These studies suggested that students must take cautionary approach while consuming caffeinated beverages owing to the harmful caffeine side effects. All the participant of this study indicated that without caffeine, they feel agitated, exhausted or depressed. Other studies explained the neurophysiologic impact of caffeine ${ }^{17,18}$ that include the benefits of caffeine such as increased arousal and decreased fatigue coupled with many disadvantages such as restlessness, increase heart rate, increase blood pressure, anxiety, and addiction and hallucination for long time of high dose. It was also found that most of the students are not aware of the such adverse effects of caffeine (62\%). Owing to the fact that these students are becoming future doctors, the same was not expected. Other studied on the subject ${ }^{1,6,10,11}$ indicated that participating 
students of those studies were educated about the adverse effects of caffeine. In this study, it was also found that majority of the student (60\%) do not feel addicted to caffeine however, only $20 \%$ of the students were willing to quit caffeine consumption.

\section{CONCLUSION}

The results showed that majority of students were using caffeine without sufficient awareness of its adverse effects, withdrawal symptoms and benefits.

\section{RECOMMENDATIONS}

1. Increase awareness among students regarding Caffeine Consumption through workshops, seminars and posters, and educate masses about harmful effect of excessive caffeine and to reduce its use to minimal quantity.

2. Student counselling services on campus should be active to discuss and resolve the student's caffeine dependence.

3. To suggest authorities to label the amount of caffeine on energy drinks so intake can be monitored.

4. Import of caffeine containing products lead to loss of foreign exchange thus affecting natural economy. Public should be informed about this economy loss by electronic and print media and through all types of community leaders.

5. Campaign at national levels, in educational institute and hospitals should be held to educate the people about negative effects of caffeine usage on health as well as national economy.

6. Cutting back on caffeine by consuming drinks such as green tea which contains low amount of caffeine as compared to other beverages stated in this study.

7. Eating healthy food, getting enough sleep and regular exercise should be practiced in order to reduce dependence on caffeine and minimize withdrawal symptoms.

Copyright@ 30 May, 2020.

\section{REFERENCES}

1. Ferré S, Díaz-Ríos M, Salamone JD, Prediger RD. New developments on the adenosine mechanisms of the central effects of caffeine and their implications for neuropsychiatric disorders. J Caffeine Adenosine Res. 2018 Dec; 8(4):121-30.

2. Ritter J, Lewis L, Mant T, Ferro A. A textbook of clinical pharmacology and therapeutics, 5Ed. Hoboken: Taylor and Francis; 2012. 476 p.

3. Lee K, Human G, Fourie J, Louw W, Larson C, Joubert G. Medical students' use of caffeine for 'academic purposes' and their knowledge of its benefits, sideeffects and withdrawal symptoms. South Afr Fam Pract. 2009; 51(4):322-7.

4. Ahmad M, E Hinna R, Tayyab A. Knowledge and trends of caffeine consumption among medical and non medical students of Lahore Pakistan. Pak J Neurol Sci PJNS. 2017; 12(2):24-30.

5. Ullrich S, de Vries YC, Kühn S, Repantis D, Dresler M, Ohla K. Feeling smart: Effects of caffeine and glucose on cognition, mood and self-judgment. Physiol Behav. 2015 Nov; 151:629-37.

6. Winston AP, Hardwick E, Jaberi N. Neuropsychiatric effects of caffeine. Adv Psychiatr Treat. 2005 Nov; $11(6): 432-9$.

7. Gonzaga LA, Vanderlei LCM, Gomes RL, Valenti VE. Caffeine affects autonomic control of heart rate and blood pressure recovery after aerobic exercise in young adults: A crossover study. Sci Rep. 2017 Oct 26; 7(1):14091.

8. Quintanilla G, Usarralde Á, Pérez I, Gargiulo ML, Yakupoglu G, Martín A, et al. Anodic oxidation of caffeine and theophylline in glacial acetic acid. ChemistrySelect. 2016 Mar; 1(3):414-6.

9. Milovanovic DD, Jakovljevic M, Scekic M, Djordjevic N. Caffeine consumption patterns and determinants among adolescents in Serbia. Int $\mathrm{J}$ Adolesc Med Health. 2018; 30(4):364-7.

10. Hidiroglu S, Tanriover O, Unaldi S, Sulun S, Karavus M. A survey of energy-drink consumption among medical students. J Pak Med Assoc. 2013; 63(7):842-5.

11. Valek M, Laslavi B, Laslavi Z. Daily caffeine intake among Osijek High School students: Questionnaire study. transition. 2004; 4:11.

12. Turki YA, Alenazy B, Algadheeb AR, Alanazi M, Almarzouqi AS, Alanazi A, et al. Caffeine habits among medical students in King Saud university. Int J Sci Res. 2016; 5(2):754-64. 
13. Iqbal TA, Maken ZH, Shemaila S, Mazhar SS, Kalsoom $\mathrm{N}$, Areej $\mathrm{F}$, et al. Use of caffeine intake among medical students during examinations in a public sector medical college of Pakistan. Pak J Public Health. 2016; 6(2):32-35.

14. Khan MS, Nisar N, Naqvi SAA, Nawab F. Caffeine consumption and academic performance among medical students of Dow University of Health Science (DUHS), Karachi, Pakistan. Ann Abbasi Shaheed Hosp Karachi Med Dent Coll. 2017; 22(3).

15. Bonnar D, Gradisar M. Caffeine and sleep in adolescents: A Systematic Review. J Caffeine Res. 2015 Sep; 5(3):105-14.
16. Banimustafa RA, Abuelbeh IA, Mu'nes AA, Safi MM, Nawaiseh MB. Caffeine consumption among the medical students at the University of Jordan. Editor Assist. 2017; 28(1):117-122.

17. Mahoney CR, Giles GE, Marriott BP, Judelson DA, Glickman EL, Geiselman PJ, et al. Intake of caffeine from all sources and reasons for use by college students. Clin Nutr. 2019; 38(2):668-675.

18. Lieberman H, Marriott B, Judelson D, Glickman E, Geiselman P, Giles G, et al. Intake of caffeine from all sources including energy drinks and reasons for use in US college students. FASEB J. 2015; 29(1):392-1.

AUTHORSHIP AND CONTRIBUTION DECLARATION

\begin{tabular}{|c|l|l|l|}
\hline Sr. \# & \multicolumn{1}{|c|}{ Author(s) Full Name } & \multicolumn{1}{|c|}{ Contribution to the paper } & Author(s) Signature \\
\hline 1 & Uzma Hassan & $\begin{array}{l}\text { Corresponding and Single } \\
\text { author. }\end{array}$
\end{tabular}

